\title{
Governing the Global Economy with the One-Size-Fits-All Model: From Ideology to Reality
}

\author{
Catherine C. $\mathrm{Lai}^{1} \&$ Matthew C. $\mathrm{Li}^{2}$ \\ ${ }^{1}$ Manchester Business School, University of Manchester, UK \\ 2 School of Management, Royal Holloway University of London, UK \\ Correspondence: Matthew C. Li, School of Management, Royal Holloway University of London, Egham, Surrey, \\ TW20 0EX, UK. E-mail: matthew.li@royalholloway.ac.uk
}

Received: February 18, 2015

Accepted: March 18, 2015

Online Published: April 8, 2015

doi:10.5430/rwe.v6n2p1

URL: http://dx.doi.org/10.5430/rwe.v6n2p1

\begin{abstract}
Over the past few decades, globalization has provided many countries with opportunities, but it also comes with the challenge of international market failure. This paper has two objectives. First, we aim to provide a chronological account that traces global policy roots of market fundamentalism and collective action; and articulates the evolving role and power structures of international players in claiming, for the common interest, to provide global public good of financial stability. This approach succinctly demonstrates the varying ideological underpinnings in the continued pursuit of international standards to manage negative externalities of globalization. Second, by constructing three composite indexes of macroeconomic and financial factors for eleven countries, we assess the effectiveness of collective action in tackling market failures during the Asian financial crisis of 1997 and the global credit crisis of 2007. Overall, we find a substantial gap between public policy subscription and actual needs of those crisis hit economies.
\end{abstract}

Keywords: globalization, market failure, public goods, externalities, international financial regulation, financial crisis

\section{Introduction}

Over the past few decades, undoubtedly the core issue facing international financial communities is globalization. In order to reap the benefits of globalization, it is imperative that international monetary authorities are attuned to the associated challenges of market failure such as negative externalities and global public goods. History has shown us that adverse financial events bear direct effects on the development of financial regulations. Indeed, financial crisis has often acted as a catalyst in changing global financial governance and bringing forth the notion of collective action. After a series of summits following the outburst of the US financial turmoil of 2007, the Group of Twenty (G20) in their summit of November 2011 made a declaration - "Building our Common Future: Renewed Collective Action for the Benefit of All" (G20 2011). Stiglitz (1999, 2002a) maintains that the provision of global public goods underpins the central part of the premise that global collective action can potentially address any types of market failure, such as global externalities. Whenever market failure occurs either in the form of externalities or public goods, there is a possible role for government intervention in formulating policies to either alleviate or overcome such failures. International spillovers of financial instability of the Asian Financial Crisis (AFC) of 1997 underlined the problems of collective action, including combating 'races to the bottom' on regulatory measures that national interests or inattentiveness can stimulate and lead to the under-provision of global public good of international financial stability (Wyplosz 1999). Similarly, in the wake of the recent Global Credit Crisis (GCC) of 2007, Sheng (2009:v) reiterates the challenge for globalization in dealing with the collective action problem and avoiding 'a race to the bottom', and emphasizes that "global public good is being consumed by unfettered greed...".

The concept of global public goods and externalities could provide powerful tools for the analysis of global governance. At the same time, it could also be argued that a comprehension of international externalities and the consequential search for global public goods, in the form of international standards for financial stability, could be useful for analyzing international regulatory developments. In essence, there is a supposedly interesting 'reverse causation' perspective that needs to be considered, in that analyzing regulatory responses to financial crises, and the pursuit of financial stability, can tell us much about the role played by international standards in the process of global 
governance. Based on such a premise, a mixed thematic and chronological approach is used to structure this paper for three main reasons. Firstly, the thematic structure facilitates an understanding of the application of the economic logic of collective action in promoting international standards for financial stability, which sought to correct market failure in financial and real markets in the globalized economy without a 'global government'. Secondly, while the pursuit of international financial standards originated from the financial crisis of the late 1990s, a historical account shows that there has been varying ideological underpinnings behind the persistent pursuit of international standards over the last decades. Thirdly, the chronological account also serves to demonstrate some intriguing evolutions in power structures (incorporating the move from the G7 to the G20) embedded in the international cooperative mechanisms seeking to respond to the financial crises of different geopolitical characteristics, viz. Asian developing countries in 1997 and the US in 2007.

Overall, this paper has two aims. First, we collate various studies, research and commentaries from a multidisciplinary perspective and synthesize them to examine how the issues of market failures, global public goods, international financial regulation and collective action have been addressed across time. Second, by employing three composite indexes of macroeconomic and financial factors, we assess the effectiveness of collective actions in tackling market failures which occurred during the turbulent times of the two major financial crises. To these ends, Section 2 lays the background for the advancement of market fundamentalism and elaborates on the application of the economic logic of market failures and the theory of global public goods to the establishments of the IMF and the World Bank. It follows with a discussion on the global policy roots of market fundamentalism, i.e. the 'Washington Consensus' and the 'Capital Account Liberalization' (CAL), and the challenges presented by financial globalization, $v i z$. financial instability. Sections 3 and 4 articulate the continued pursuit of international standards which aimed at correcting negative global externalities. In the absence of a global government, these two sections reveal the ideology underpinnings of the pursuit of international standards. Section 5 describes the construction of the composite indexes for our examination of the two financial crises. Movements of the three sectors - economy, trade and finance for the eleven countries that had been affected by the AFC of 1997 and GCC of 2007 are studied. Section 6 presents post-crisis developments in the international financial regulatory regime such as the evolution of assemblages of collective action designed to strengthen international cooperation and avoid regulatory arbitrage. Section 7 offers concluding remarks and distinguishes the varying ideological underpinnings in international regulatory developments in response to the diverse nature of negative global externalities which occurred during these two financial crises. Remarks on policy appropriateness/effectiveness on the management and prevention of financial crises are also provided.

\section{Market Failures: Negative Global Externalities and Global Public Goods}

\subsection{The IMF and the World Bank}

The negative global externalities of countries' 'beggar-thy-neighbour' (Note 1) policies of trade restrictions and competitive exchange rate devaluations were seen as contributing factors to the Great Depression of the 1930s in the US. The fact of countries running trade surplus or trying to restore their own economic strength at the expense of their trading partners reflected a form of global externality that demanded collective action at the global level (Stiglitz 2002a). With the perception of the failure of international economic order, the International Monetary Fund (IMF) and the World Bank were desired to prevent the conditions that had contributed to the Great Depression being repeated after the Second World War, and thereby avoiding any return to the 'beggar-thy-neighbour' policies of the pre-war period (Stiglitz 1998, 2002a, 2006; Eatwell \& Taylor 2000). Purposely, the IMF and the World Bank were instituted to set up an international economic regulatory regime for the post-war period and to facilitate economic cooperation and collective action at the global level. While the creation of these institutions reflected the recognition of the gravity of market failures, the IMF preached market fundamentalism and explicitly believed that market systems could, by themselves, solve all economic problems (Stiglitz 2008a, 2008b).

With changes in financial realities since the inception of these institutions in 1944, Stiglitz (2002a, 2006) subsequently criticized the IMF's actions in the international economic environment in seeking to provide global public goods for economic stability. He argued against the counter-productive policy advice of the IMF on capital market liberalization which resulted in spill-over effects on others through the phenomenon of contagion. Capital market liberalization was indeed condemned as the main cause of the contagion that fuelled the 1997 AFC (Williamson 2000; Singh 2002). In addressing contagion and financial instability, dynamic assemblages of collective action have emerged and evolved over the last decades seeking to correct market failures in the age of a globalized financial world. 


\subsection{Globalization and Market Fundamentalism: 'Washington Consensus' and CAL}

In the process of globalization, the ideology of liberalization or free market beliefs and the associated policy measures through the 'Washington Consensus' by the late 1990s played an influential role in the march towards globalization. Under the encouragement of the IMF, the World Bank, and the American and British governments, developing countries increasingly adopted the prescriptions of the 'Washington Consensus' or 'Globalization Consensus' (Wade 2008), with the 'third world' reportedly becoming more receptive to establishing policies towards deregulation and liberalization.

According to Williamson (2000), the 'Washington Consensus' had come to be used as a phrase to describe an ideological position and represented "an extreme and dogmatic commitment to the belief that markets can handle everything” (p.252). Stiglitz (2008a) views the 'Washington Consensus' as a set of policy advice emphasizing trade liberalization, macroeconomic stability, privatization and getting prices right, in order to achieve a relatively narrow goal of economic growth relying on market fundamentalism. Rodrik (2001) and Wade (2008) categorize it as a prescription of global economic policy pertinent to privatization, liberalization and openness, grounded on the notion that all governments should liberalize and deregulate the markets. These commentaries clearly indicate that the periods prior to the later 1990s signify the ideology of liberalization and free market which believes in deregulation and market mechanism.

The beliefs in financial liberalization and free market are not only supported by policy measures and reform advice of the 'Washington Consensus' (Note 2), but also by the IMF through its commitment to CAL advocating the lifting of capital controls. The policy advocacy of CAL and the 'Washington Consensus' has led to an increased economic integration among countries in the world economy. The free flowing nature of capital movements was claimed from the theoretical viewpoint to help channel resources into their most productive uses both nationally and internationally (Fischer 1997; Camdessus 1998; Kose \& Prasad 2004). That said, "any thought of successful economic isolation seems more and more unrealistic... small emerging economies, as never before, have become convinced that they cannot benefit at all fully from international trade without a high degree of financial openness" (Volcker 2000:207).

\section{Globalized Economy without a Global Government}

In the absence of a 'global government' in the international regulatory arena, or more precisely a global governmental role in correcting market failure in the form of macroeconomic instability in the international financial system, Eatwell \& Taylor $(1998,2000)$ propose to set up a 'World Financial Authority' (WFA) to provide a "framework of truly international regulation" (Eatwell 2002:12). When faced with negative global externalities such as financial volatility contagion, the proposed WFA would help to develop policies for managing global systemic risk, in a form that would parallel the work of the World Trade Organization (WTO) with respect to trade issues (Eatwell \& Taylor 1998). Considering the traditional prerogatives of national sovereignty, this proposal of a WFA has been argued by Eichengreen as politically unrealistic and "... must be dismissed as quixotic..." arguing that while we might be in the age of global markets, we are not in an age of global government (Eichengreen 1999:2).

Eichengreen's scepticism is based on what he sees as the reluctance of countries to compromise their sovereignty and delegate national financial regulations to any supranational authority. In dealing with such practical issues of sovereignty, Eichengreen suggests an alternative approach of imposing an obligation on countries to join a proposed 'World Financial Organization' (WFO) with the core function of strengthening the international financial system regarding dispute settlements for finance and for preventing contagion and future global financial crises.

While neither the establishment of the WFA nor the WFO has yet to be materialized, the structure of global financial governance has evolved when faced with new challenges in globalization. Grounded on the logic of market failure and the absence of a global government, the theory of global externalities suggests that global public goods require collective action (Stiglitz 2002a, 2006). Sharing Eichengreen's concerns about countries' unwillingness to surrender sovereign authority over national financial markets and institutions, Acharya, Wachtel, \& Ingo (2009) emphasize that international coordination is necessary for improving international regulatory structures and for tackling common problems in the process of globalization. The organizational implication of such behaviour patterns is that transnational actors and international organizations active in the regulatory sphere have to become globalized in order to address global issues beyond national political boundaries and autonomies. Similarly, according to Volcker (2000:207), the "implication of globalism is globalism". In the international community, there has been more reliance on consensus and more delegation to specialized bodies supposedly consisting of experts to deal with collective problems or to remove the "building blocks for making globalization work in the common interest" (Volcker 2000:214). In the quest for the common interest of international financial stability, the collective action of 
elite groups in the international community has reached a consensus of pursuing international standards in order to mitigate contagion risks arising from policy interdependence following the financial crisis of the late 1990s.

\section{Ideology Underpinnings of International Standards}

\subsection{The Pursuit of Global Public Goods of International Standards and Financial Stability}

Shortly after the eruption of the AFC in mid-1997, a coalition of the US, the G7 and the IMF pleaded to take concrete steps expeditiously in managing the negative global externalities of contagious financial market volatility and macroeconomic instability. Grounded on the premise of contagion risks arising from policy interdependence, a developing fundamental policy imperative of the international community was to reinforce international cooperation and coordination. Responding to the mandate of the G7 for international cooperation (G7 1998), the Financial Stability Forum (FSF) was established in April 1999 for improved cooperation in financial supervision and surveillance for international financial stability. The FSF essentially manifested a new form of collective action to solidify the developing rules of global governance in the global policy arena. Eatwell \& Taylor (2000) regard it as a form of coordination in installing common standards and procedures rather than relying solely on cooperation; but without the control power mediated by treaty or similar statutory powers in terms of policymaking, surveillance and enforcement responsibilities. Notwithstanding this lack of power, the creation of the FSF came to represent a shift in the balance of collective action in the global policy arena: from the dominance of the G7 and the IMF to a greater degree of influence for a group of international organizations and standard-setting bodies or regulatory agencies in charge of the demanded international standards and codes. (Note 3)

Such pursuit of financial standards and codes was viewed as an 'augmented Washington Consensus' - a second-generation set of reforms to refurbish the view of 'Washington Consensus' on economic policy with new international standards and codes in governing the global economy (Rodrik 1999, 2001). This new consensus essentially complemented the 'Washington Consensus' by promoting international standards and codes as a way of enhancing transparency and strengthening financial regulation and supervision.

4.2 The Rise of 'Soft' Law in International Financial Regulation and the New International Financial Architecture (NIFA)

The reform of the global financial architecture is a term "intended to suggest a major change in the rules of the game that would prevent another crisis" (Stiglitz 2002b:233). The set of international standards has become what North (2005) and Porter (2005) define as formal rules or informal tools in the game of global financial governance. Kerwer (2005) views the set of international standards for sound financial systems as a proliferation of standards in global financial regulation. Although most of the standard-setting bodies have no legal capacities to promulgate 'hard' law, international financial standards have developed as international 'soft' law mainly due to their voluntary and non-legally binding or non-treaty role in international financial regulation (Brummer 2010).

\subsection{Legitimating Financial Liberalization - The 'post-Washington Consensus'}

Since the AFC, the set of international standards has developed as one of the major pillars of the NIFA, which Wade (2007) coins as the 'standards-surveillance-compliance' regime or the 'post-Washington Consensus'. Wade characterizes the reforming spirit of such a regime as representing a move from 'liberalizing the market' to one of 'standardizing the market' on a global scale. The NIFA has also been characterized as representing a change from the embedded liberalism of the post-war financial system of the Bretton Woods regime to a new 'transparent liberalism', a strange hybrid of neoliberal and embedded liberalism imposing a new norm of transparency (Best 2003). This new regime was also argued as normalizing and legitimating the ideology of free market and financial liberalization. Wade (2007) maintains that the 'standards-surveillance-compliance' regime has pushed national economies towards the Anglo-American type of capitalism while shrinking the scope of policy space for developing countries. Considering different stages of financial sector development and heterogeneity across countries, Eichengreen (2005) comments that the "one-size-fits-all" advice in managing capital account liberalization would be unlikely to be productive. Rodrik (2009) argues that "global financial regulation [in terms of "one-size-fits-all"] is neither feasible, nor prudent, nor desirable"; and he advocates the setting of some sensible international rules that will allow nations to formulate their own regulations while preventing adverse spill-overs, depending on countries' preferences and levels of development.

\section{Effectiveness of the One-Size-Fits-All Model of Collective Action: Evidence from Turbulent Times}

During the past two decades, the global economy has experienced two major turbulent time periods in which various countries were adversely affected. The two most significant events that epitomise these turbulent times are the AFC of 1997 and the GCC that started in the US in 2007. To fulfil the second aim of this paper, we investigate the 
suitability of the "one-size-fits-all" public policy model through analyses of three composite indexes that are constructed for eleven countries which suffered from negative impacts of these two financial crises.

\subsection{Composite Indexes and Volatility}

Specifically for this paper, three composite indexes are constructed and used to study the appropriateness of policies that have been put forward in the international arena for managing and preventing global financial instability. By using macroeconomic and financial data and following the procedure proposed by the Conference Board,(Note 4) three composite indexes are calculated. These indexes represent the three major sectors in an economy and we categorize them as: 1) Economy; 2) Trade; and 3) Finance. The economy index is an indicator of domestic real economy and is calculated based on four components: GDP growth, national debt, inflation and unemployment. The trade composite index represents external competitiveness of a country, and the two components are exchange rates and trade balance. The finance index presents the condition of the financial markets and the two constituents are equity prices and interest rate spreads.(Note 5) Upon the construction of these indexes, their volatilities are estimated by using a generalized autoregressive conditional heteroskedasticity- GARCH $(1,1)$ model. There is over-whelming evidence of the time-varying conditional variance of financial and macroeconomic data. The GARCH model is a frequently used volatility measure that takes into account of this possibility. The volatility of these three composite indexes offers us a snapshot of the degree of effects that these three sectors experienced during the two financial crises. Comparing the index movements with the international policy attention, we should have a clear picture about the appropriateness of policy focus, in particular regarding the "one-size-fits-all" model. Eleven countries are selected for this study, namely: Thailand, Malaysia, Korea, Indonesia, Hong Kong, (Note 6) Greece, Spain, the US, Ireland, Iceland, and the UK. These countries are chosen due to the fact that they were subjected to the impacts of either the AFC of 1997 or the GCC of 2007.

\subsection{The AFC, 1997-99}

\subsubsection{The Crisis}

In 1997, following the collapse of the Thai baht, it sparked a panic that drove down currencies and later turned into a crisis. The destructive effects of financial liberalization were reflected in exchange rate volatility, financial and macroeconomic instability; and subsequent impacts on the real economy, such as unemployment (Kenen 2001). The spread of the AFC was followed by the devastating spill-over or neighbourhood effects on peripheral countries, such as Malaysia, Indonesia, Korea and Hong Kong. The negative externalities and the repercussions from the Asian crisis countries inflicted on other countries provoked systemic worldwide implications. The negative neighbouring effects of macroeconomic instability on other countries were transmitted by both the phenomenon of contagion and hot money movements channelled by capital market liberalization. Capital inflows to and outflows from developing countries can often be procyclical, for instance the sudden and enormous reversal of short-term flows amounted to over 10\% of GDP in East Asia during the AFC (Stiglitz 1999). In essence, the spill-over or neighbourhood effects of this financial crisis were transmitted mainly through volatile and speculative short-term capital flows, the herding behaviour patterns of investors, leading to financial contagion, i.e. the reversal of capital inflows from emerging economies (Alexander et al. 2006). The diffusion of negative global externalities during the AFC reflected international market failure where crisis-stricken countries did not have the incentive or were not able to internalize the external negative impacts of contagion borne by other, often neighbouring countries. This situation called for a potential role of governmental action in the global context to manage global systemic risk. Subsequent to the crisis, the prevalent view shared by academics and international institutions is that in managing the challenge of financial instability, it gave rise to the need for providing the global public good of financial stability to the international financial system, the benefits of which are, theoretically, supposed to accrue to everyone universally. 
5.2.2 Policy Focus and Volatility Analysis

1a: Thailand

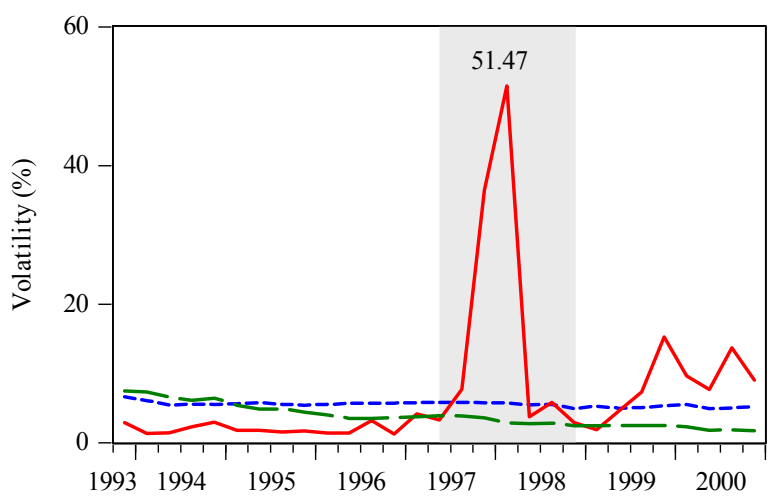

---- Economy — Trade - - Finance

1c: Korea

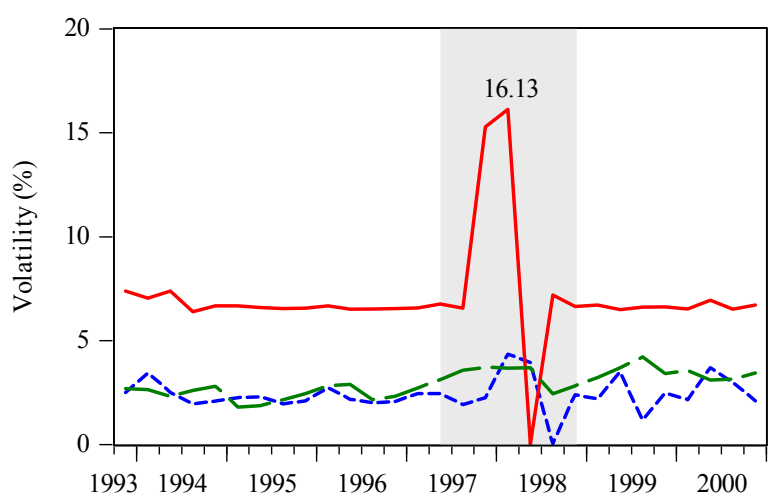

---- Economy — Trade —- Finance

1e: Hong Kong

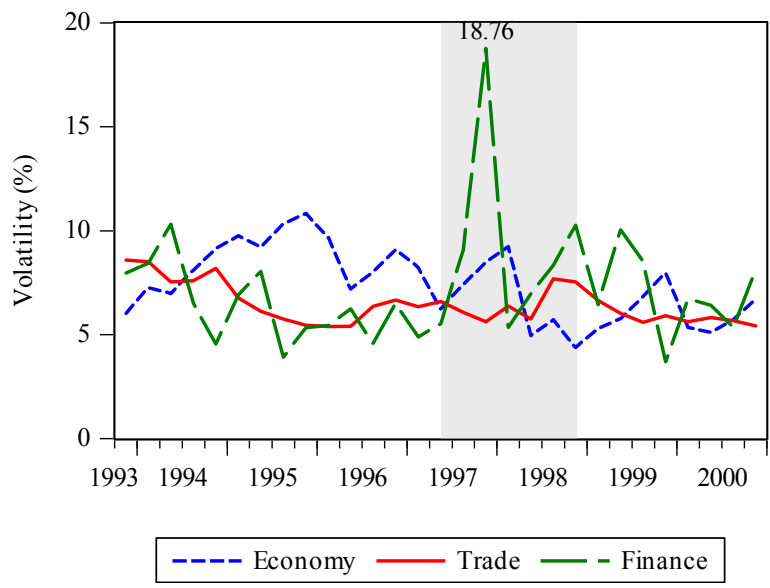

1b: Malaysia

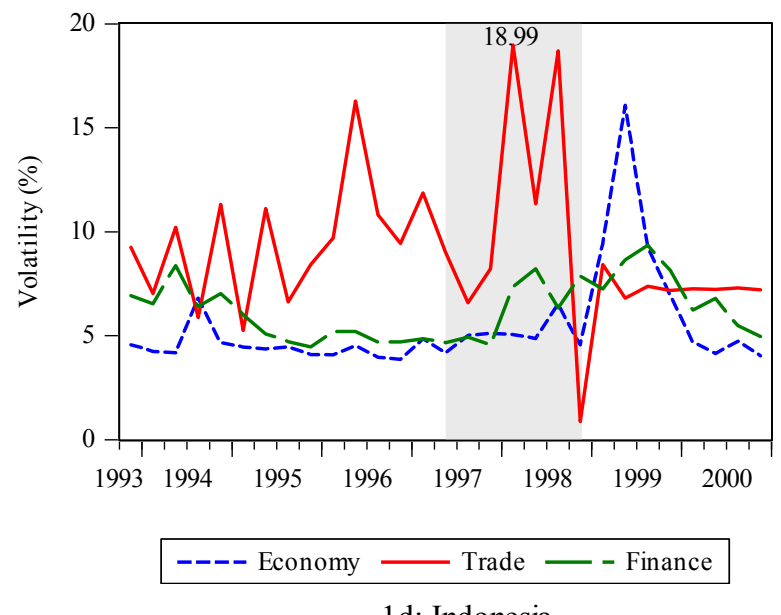

1d: Indonesia

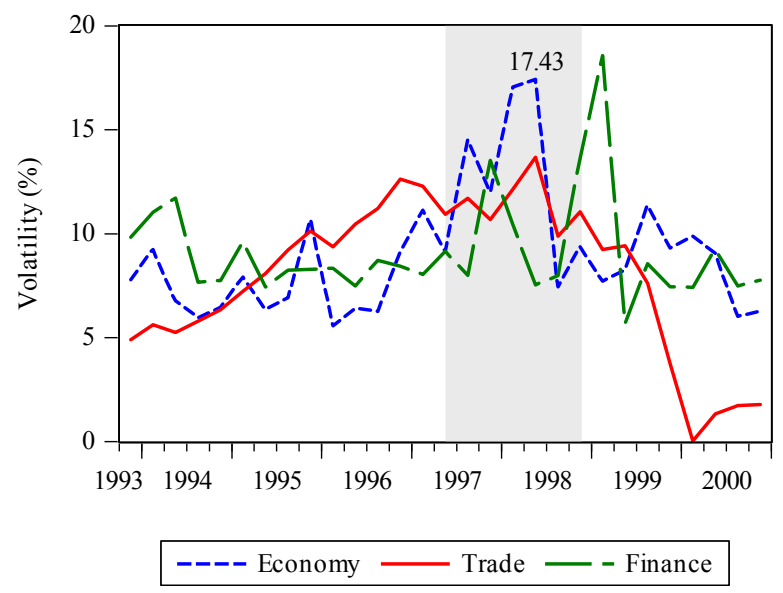

Figure 1. Composite index volatility of (a) Thailand; (b) Malaysia; (c) Korea; (d) Indonesia; (e) Hong Kong. Whole sample period: 1993Q4 through 2000Q4. Shaded area shows AFC period 1997Q2 - 1998Q4

Understandably, due to the fact that the crisis was initiated in the financial sector, primary consideration was put into maintaining stability in the international financial system. Figure 1 presents the composite indexes of the five 
countries: Thailand, Malaysia, Korea, Indonesia, and Hong Kong, which were affected by the event. The shaded area in the five panels highlights the crisis period 1997Q2 though 1998Q4 for the five countries and it is apparent that the effects are rather disparate. Panels $1 \mathrm{a}, 1 \mathrm{~b}$ and $1 \mathrm{c}$ demonstrate that during the AFC, Thailand (51.47\%), Malaysia $(18.99 \%)$ and Korea $(16.13 \%)$ experienced high volatility in the trade sector (external competitiveness as measured by the two components, exchange rates and trade balance), whereas the economy and finance sectors remained relatively stable. In panels $1 \mathrm{~d}$ and $1 \mathrm{e}$, we observe that the crisis caused the biggest fluctuations in the Indonesian economy index (17.43\%) and the Hong Kong finance index (18.76\%). According to the figures presented in Larionova (2011), during the Birmingham 1998 and the Cologne 1999 summits, the three sectors: economy, trade, and finance, constituted an average of $27 \%, 1.6 \%$, and $10 \%$ respectively on the G8 agenda. Our results show succinctly that a divergence existed between international policy priority and country-specific needs. This surely suggests that the amount of attention paid to the trade and finance sectors was grossly insufficient to reflect the actual circumstance during the AFC. In other words, while collection action following the one-size-fits-all model would help some countries to mitigate the adverse impacts of the crisis, not all countries would benefit equally.

\subsection{The GCC, 2007-10}

\subsubsection{The Crisis}

The US subprime mortgage crisis and the succeeding credit crunch started in 2007 served as a prelude to the GCC that lasted until 2010. (Note 7) While speculative attacks on some of the Asian currency systems led to the AFC of 1997, the GCC of 2007-10 was chiefly due to flaws in the regulatory system. Contrary to the argument of advantageous banking standards for developed countries that follow the Anglo-American model, regulatory gaps in prudential standards could still contribute to financial crisis in such countries. Specifically, the systemic implications of the regulatory gaps in the US subprime mortgage sector for the global financial system were evident during the GCC. Although the pursuit of international standards or 'soft' law aiming at preventing crisis had burgeoned since the late 1990s, it did not avert the 2007 crisis. The resulting market failure demonstrated clear gaps between the ideology of pursuing international standards for crisis prevention and national regulatory commitments to adopting these standards.

While the core purpose of financial regulation is said to be to reduce the likelihood of crisis or mitigate systemic risks (Eatwell \& Taylor 2000; Eatwell 2008), major failures in the financial sector and in financial regulation and supervision were identified as the fundamental causes of the GCC. Mistakes in the deregulatory ethos and free market ideology were deemed to be responsible for the financial meltdown or credit 'tsunami' - the "once-in-a-half-century, probably once-in-a-century type of event" (Greenspan 2008, 2009).(Note 8) The US regulatory systems failed to keep up with institutional or structural changes and the financial innovation that drove highly leveraged institutions in financial markets (FSF 2008a). The resulting regulatory lapses allowed institutions to gear up without sufficient corresponding regulatory capital. The lax regulations concerning the securitization of the US subprime mortgage market and the associated accounting treatments duly triggered a series of repercussions across borders.

The liquidity crisis was further amplified by procyclical effects. Procyclicality refers to the mutually reinforcing mechanisms through which the financial system can amplify business fluctuations and possibly cause or exacerbate financial instability (BIS 2008). As a result of worsening levels and terms associated with external funding arrangements, financial institutions cut credit extensions and disposed of assets. The Geneva Reports on the World Economy, 'The Fundamental Principles of Financial Regulation', referred to the impact of the disposal of assets as 'fire-sale externalities', seeking to emphasize that each individual financial institution does not take into account the effect of its own fire-sales on asset prices and any subsequent liquidity crunch (Brunnermeier et al. 2009).

The systemic impacts of procyclical externalities were exacerbated by financial market inter-linkages among systems and across national borders. A view shared by Acharya, Lasse, Philippon, \& Richardson (2009); Brunnermeier et al. (2009) and D'Arista (2009) is that such externalities were accelerated by high levels of institutional interconnectedness, where the failure of big and interconnected institutions would bring down the negative risk-spillover effects on others. Stiglitz (2010) describes the situation as one in which agency and corporate governance problems in financial institutions contributed to the pervasive externalities as they misaligned private and social interests.

The presence of negative externalities among financial institutions and the systemic risks imposed by individual financial firms justified the strengthening of financial regulation as a way to mitigate their potential impacts. In other words, the market failure manifested in systemic risk has to attract the concerns of public policy in formulating financial regulation (Alexander et al. 2007). In the international public policy arena without a global government, the 
FSF facilitated international coordinated action for preserving a level playing field across countries. Aiming at mitigating the systemic impacts of procyclicality across national and sectoral boundaries, the FSF tracked down drivers of procyclical behaviour such as fire-sale externalities. In light of their procyclical impacts, the required capital cushion and lending capacity of financial institutions, together with fair value or mark-to-market accounting were also put under the spotlight in a global policy agenda seeking to restore market confidence in, and the institutional resilience of, the global system (FSF 2008b).

In response to the market failure of international externalities amplified by procyclicality, and following a request by the G7 Treasury deputies, the FSF established a 'Working Group on Market and Institutional Resilience' (hereafter, the FSF Working Group) comprising representatives of national authorities and international organizations to seek measures for enhancing market discipline and institutional resilience of the financial system. While these policy measures were intended to build confidence and bolster market resilience, the FSF Working Group had reservations about expanding the scope of regulatory coverage to solve the problem of market failure as additional regulations could create areas for regulatory arbitrage or new market distortion (FSF 2008a). In February 2008, the Group argued that "not every market failure in financial systems has an appealing or effective regulatory solution" (FSF 2008a:5). With the unfolding turmoil on a global scale two months later, they recommended authorities to decide where prescription was necessary for the "collective action problems and other market failures" (FSF 2008b:10). Six months later, striking repercussions as of early October 2008 cut across borders from the US and the UK to many continental European banks. It became apparent that the globalized nature of financial markets spread the US subprime mortgage losses out to other parts of the world, especially to some European financial institutions.

\subsubsection{Policy Focus and Volatility Analysis}

2a: Greece

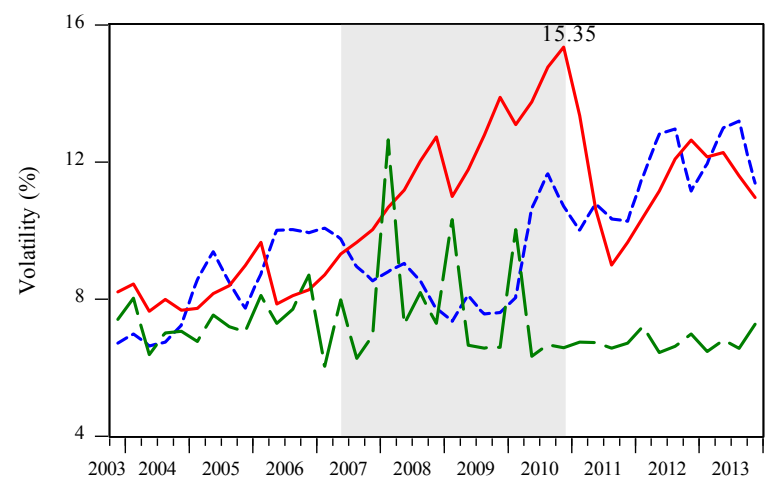

---- Economy — Trade - - Finance

2c: US

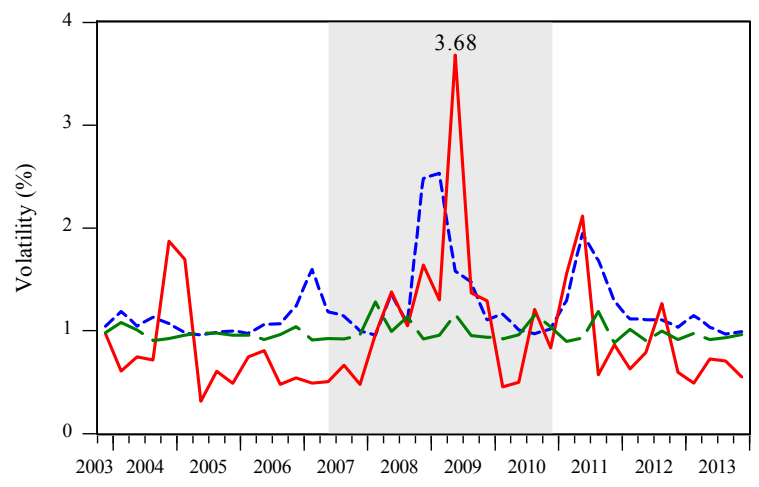

---- Economy $\longrightarrow$ Trade - - Finance 2b: Spain
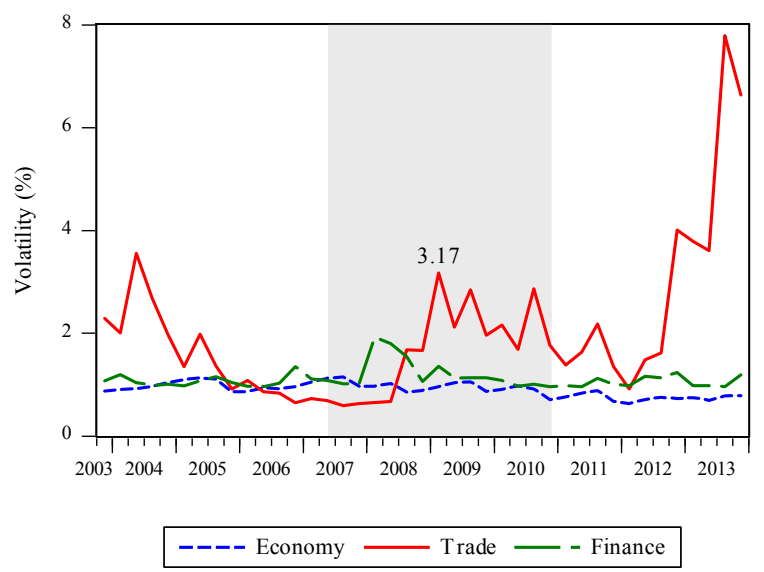

2d: Ireland

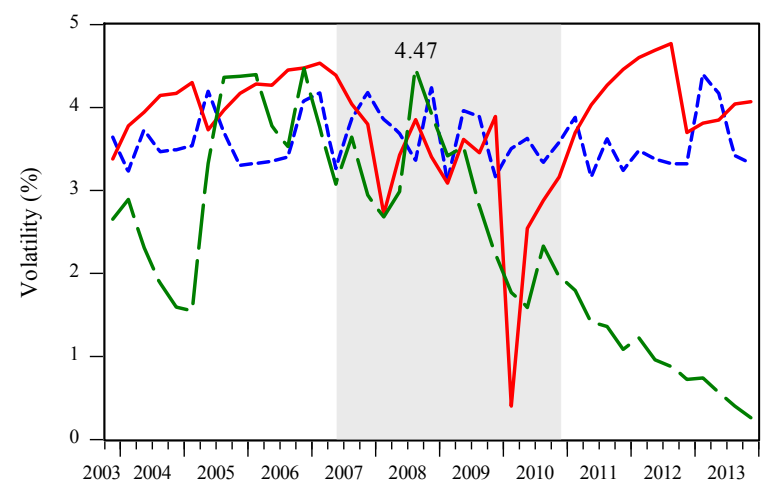

---- Economy — Trade — - Finance 
2e: Iceland

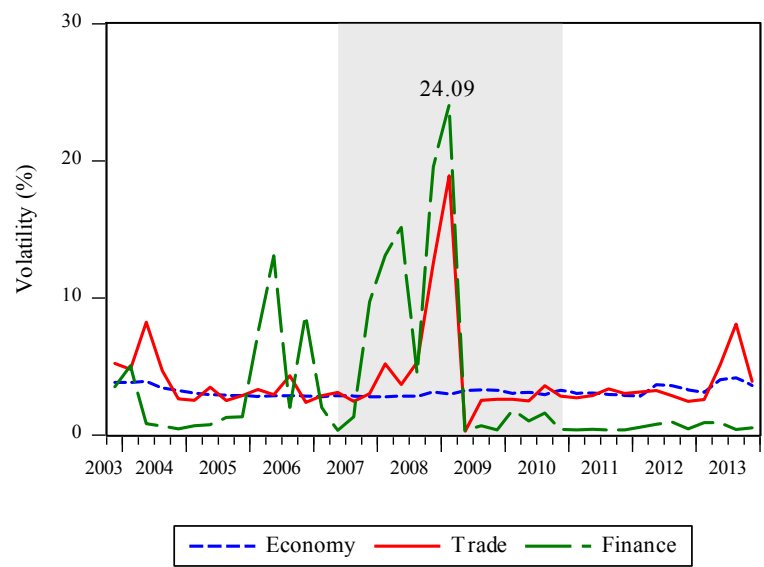

2f: UK

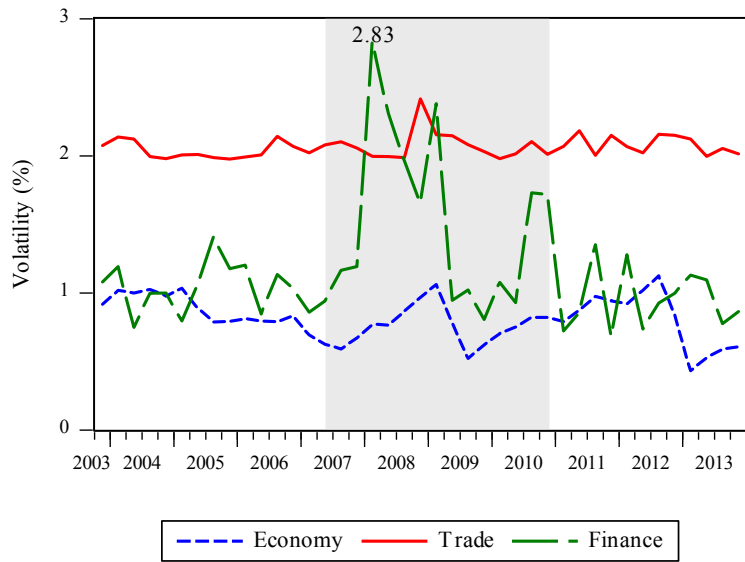

Figure 2. Composite index volatility of (a) Greece; (b) Spain; (c) US; (d) Ireland; (e) Iceland; (f) UK. Whole sample period: 2003Q4 through 2013Q4. Shaded area shows GCC period 2007Q2 - 2010Q4

The six panels of Figure 2 provide us with a snapshot of what happened in our six chosen countries: Greece, Spain, the US, Ireland, Iceland, and the UK, during the GCC. By assigning 2007Q2 through 2010Q4 as the crisis period for our investigation, Figure 2 shows us that not all countries shared the same pattern of adverse effects. For countries such as Greece (15.35\%), Spain (3.17\%), and the US (3.68\%), the crises caused relatively high volatility in the trade sector, whereas the finance sector was significantly affected in Ireland (4.47\%), (Note 9) Iceland (24.09\%), and the UK (2.83\%). However, according to statistics offered by Larionova (2011), during the period 2008 to 2011, agenda priority for the G8 was: economy $(3.82 \%)$, trade $(2.52 \%)$, finance $(0.87 \%)$, and for the G20, the percentages for the three sectors were: economy $(23.39 \%)$, trade $(2.28 \%)$, finance $(61.15 \%)$. Although our study shows that the sector that generated high volatility was mostly in trade, the actual attention devoted to trade was greatly incommensurable. Again, in this case, we see the gap between policy priority on the international agenda and the actual conditions of those affected countries remains substantial. This difference could potentially mean that policies advocated on the global policy agenda could be mismatched or ineffective in alleviating the effects of negative global externalities; promoting recovery in some crisis-stricken economies; and preventing future crises. In other words, international policy approach with limited flexibility or in the extreme case of the "one-size-fits-all" model would find it difficult to achieve the goal of economic and financial stability in the globalized world.

\section{Post Crisis Reactions}

With the "one-size-fits-all" model deeply embedded within the policy agenda, discussions and proposals among academic scholars and policy makers on how to react to and to abate negative global externalities through the use of international regulation and standards continued.

\subsection{Strengthening International Financial Regulation and International Standards}

Almost a decade prior to the GCC, the G20 had held its annual meeting of Finance Ministers and Central Bank Governors to discuss measures for promoting international financial stability.(Note 10) Only following the aftermath of the GCC, members of the G20 with the largest stake in the global trading system were called upon to further strengthen international cooperation in widening political commitment.(Note 11) It was then followed by the first G20 summit held in Washington, D. C. in November 2008. This G20 summit was expected to discuss a coordinated global policy response to the credit crisis and "promise to avoid beggar-thy-neighbour policies". In response to the global financial turbulence, the G20, through their deliberations in the years following their first summit, coupled with its commitments under the declaration of "Building our Common Future: Renewed Collective Action for the Benefit of All" (G20 2011), declared to accelerate the concerted actions in developing a collectively consistent supervisory and regulatory framework for the future financial sector to reduce the scope of regulatory arbitrage and ensure a level playing field.

In seeking to catch up with the regulatory deficiency or the lag associated with standard-setting and financial innovations, inter alia, the areas of banking supervision and international accounting rules have merited a great deal of attention and commanded prompt actions post-2007. In September 2010, in response to calls from the G20 for 
strengthening the prudential regulation on buffer capital, the Basel III rules were launched to raise required capital ratios from $2 \%$ to $4.5 \%$ plus a new buffer of $2.5 \%$ to ensure that banks are more resilient to financial shocks.

\subsection{Reinforcing International Regulatory Cooperation}

As evident in the GCC, the adverse impact of lax national regulatory policies easily spilled over onto other countries. While the GCC became a defining moment in highlighting regulatory lapses, an enhanced institutional capacity for the FSF appeared to be necessary for securing political commitment and strengthening global international cooperation. The G20 called for reform of the FSF, demanding an expanded membership on the part of emerging economies in order to promote, more effectively, financial stability (G20 2008, 2009c). In April 2009, the FSF was duly re-established as the Financial Stability Board (FSB) with a broadened membership including all G20 countries, current FSF members, as well as Spain and the European Commission.

\subsection{Strengthening the Implementation of International Standards}

In supporting the strengthening of financial regulation and supervision, the G20 has reiterated affirmative efforts to reinforce the implementation of reforms seeking to shore up financial markets and regulatory regimes for preventing future crisis and the build-up of systemic risk (G20 2008, 2009c). A few months later, in early 2009, with the scale and spread of the crisis deepening, and global output contracting at a pace not seen since the 1930s, the G20 appealed to all countries to join collectively to search for a global solution to the global crisis for sustainable globalization (G20 2009). In April 2009, the FSB established the 'Standing Committee on Standards Implementation' to report on members' commitment to the implementation of international financial standards (FSF 2009). With the established coordinating role of the FSB in assessing financial system vulnerabilities, by January 2010, the idea of 'a race to the top' has been advocated by the Standing Committee. Nevertheless, the "one-size-fits-all" model remains firmly rooted in the public policy agenda.

\section{Concluding Remarks}

The AFC of 1997 highlighted the risks associated with the policy of CAL and the 'Washington Consensus'. The threats prompted by negative global externalities on neighbouring countries and the resultant global financial instability provoked the international community to seek measures for managing international market failure. In correcting such failure, global governmental action is necessary to provide the global public good of international financial stability. In the absence of a global government or a WFA or a WFO, building on the premise of contagion risks arising from policy interdependence and the beliefs in weak corporate governance and lack of transparency in some Asian crisis-stricken countries, the US, the G7 and the IMF developed an ideology, and subsequently through the actions of the FSF, sought to advocate the adoption of international standards for global financial stability.

Despite the existence of designed policy measures in the NIFA for crisis prevention, the eruption of the GCC that started in 2007 again emphasized the implications of contagion risks arising from policy interdependence. In the search for a global solution to a global crisis, the FSB emerged in April 2009 as a new form of collective action seeking to reinforce international regulatory cooperation.

During the periods of 1997-98 and 2007-10, the historical changes in the assemblages of collective action demonstrate the evolved shift in power structures, moving from the US, the G7 and the IMF (from the AFC) to the G20 and the IMF, together with the progressively engaging role of the FSF, through to the FSB (in the wake of the GCC). In supporting the continued ideological belief in pursuing international standards, proactive and concrete measures have been taken to advance their implementation for sound international financial regulation to avoid regulatory arbitrage and complement free market principles. Relying on the adoption of international standards for global financial stability, the sustainability of the so-called 'standards-surveillance-compliance' regime is contingent on country participation and willingness to compromise national sovereignty for fostering 'a race to the top' in international financial regulation. That said, even with more than a decade of advocacy supporting the adoption of international standards on the global policy agenda, the extent of its practical achievements hinges fundamentally on country commitments to such adoption and the suitability of the "one-size-fits-all" regulatory model. Indeed, criticisms on shrinking policy scope in developing countries or homogenizing market institutions on a global scale and those criticisms concerning the "one-size-fits-all" regulatory model remain arguable.

Our exercise of utilizing three composite indexes of macroeconomic and financial factors to examine the crisis effects provides us with an additional dimension and further insight of the extent of global policy priority matches the reality. To this end, we perform an empirical study to investigate the suitability of the so called "one-size" international regulatory model in domestic national regimes. Overall, our results indicate that not all sectors within an economy and not all countries are equally affected by the crisis. This leads us to believe that in this globalized 
world, in order to achieve stability and sustainable growth, policy priority should be made more dynamic; and hence country specific characteristics should be addressed accordingly. Reiterating Rodrik (2009)'s argument, "global financial regulation [in terms of "one-size-fits-all"] is neither feasible, nor prudent, nor desirable". Undoubtedly, collection actions in providing global public good of financial stability is desirable, however, international policy agenda that based on the "one-size-fits-all" approach would significantly diminish our chance of combating the challenge of market failures that are associated with globalization.

This paper provides a comprehensive discussion and study on the development of public policy in the international financial arena. Further research on this subject by employing empirical data to produce a more precise picture about the actual impact of these international policy measures at country level would certainly be beneficial.

\section{References}

Acharya, Viral V., Paul Wachtel, \& Ingo Walter. (2009). International Alignment of Financial Sector Regulation. In V. V. Acharya and M. Richardson (Eds.), Restoring Financial Stability: How to Repair a Failed System. New Jersey: John Wiley \& Sons.

Acharya, Viral V., Lasse, H. Pedersen, Thomas, Philippon, \& Matthew, Richardson. (2009). Regulating Systemic Risk. In V. V. Acharya and M. Richardson (Eds.), Restoring Financial Stability: How to Repair a Failed System. New Jersey: John Wiley \& Sons.

Alexander, Kern, Rahul, Dhumale, \& John, Eatwell. (2006). Global Governance of Financial Systems: The International Regulation of Systemic Risk. New York: Oxford University Press.

Alexander, Kern, John, Eatwell, Avinash, Persaud, Robert, Reoch, \& Reoch Credit Partners LLP. (2007). Financial Supervision and Crisis Management in the EU. IP/A/ECON/IC/2007-069.

Bank for International Settlements (BIS). (2008). Addressing Financial System Procyclicality: A Possible Framework. Note for the FSF Working Group on Market and Institutional Resilience. September 1.

Best, Jacqueline. (2003). From the Top-Down: The New Financial Architecture and the Re-embedding of Global Finance. New Political Economy, 8(3), 363-384. http://dx.doi.org/10.1080/1356346032000138069

Brummer, Chris. (2010). Why Soft Law Dominates International Finance-and not Trade. Journal of International Economic Law, 13(3), 623-643. http://dx.doi.org/10.1093/jiel/jgq026

Brunnermeier, Markus, Andrew, Crocket, Charles, Goodhart, Avinash, D. Persaud, \& Hyun, Shin. (2009). The Fundamental Principles of Financial Regulation. Geneva Reports on the World Economy, 11, ICMB-CEPR.

Camdessus, Michel. (1998). Capital Account Liberalization and the Role of the Fund. Remarks by Michel Camdessus, Managing Director of the International Monetary Fund at the IMF Seminar on Capital Account Liberalization, Washington, D.C., March 9.

D’Arista, Jane. (2009). Rebuilding the Framework for Financial Regulation. Economic Policy Institute (EPI) Briefing Paper 231, March 27.

Eatwell, John. (2002). The New International Financial Architecture: Promise or Threat? Cambridge Endowment for Research in Finance (CERF).

Eatwell, John. (2008). 'Greater Transparency' is the Mantra of the Ignorant. The Guardian, September 19.

Eatwell, John, \& Lance, Taylor. (1998). International Capital Markets and the Future of Economic Policy. Center for Economic Policy Analysis (CEPA) Working Paper Series III: International Capital Markets and the Future of Economic Policy, No. 9.

Eatwell, John, \& Lance, Taylor. (2000). Global Finance at Risk: The Case for International Regulation. Cambridge, UK: Polity Press.

Eichengreen, Barry. (1999). Strengthening the International Financial Architecture: Where Do We Stand? Prepared for the East-West Center Workshop on International Monetary and Financial Reform, Honolulu, October 1-2.

Eichengreen, Barry. (2005). Capital Account Liberalization and the Fund. Prepared for the High Level Seminar on Capital Account Liberalization and the IMF, held at the Swiss Ministry of Finance and convened jointly by the Finance Ministries of Belgium, the Netherlands, Sweden and Switzerland, Bern, December 12.

Fischer, Stanley. (1997). Capital Account Liberalization and the Role of the IMF. Paper prepared for presentation at the IMF seminar "Asia and the IMF", Hong Kong, September 19. 
Financial Stability Forum (FSF). (2008a). FSF Working Group on Market and Institutional Resilience - Interim Report to the G7 Finance Ministers and Central Bank Governors. February 5.

Financial Stability Forum (FSF). (2008b). Report of the Financial Stability Forum on Enhancing Market and Institutional Resilience. April 7.

Financial Stability Forum (FSF). (2009). Re-establishment of the FSF as the Financial Stability Board. Prepared remarks by Mario Draghi, Chairman of the Financial Stability Forum, at conclusion of London Summit. April 2.

G7. (1998). Declaration of G7 Finance Ministers and Central Bank Governors. October 30.

G20. (2008). Declaration of the Summit on Financial Markets and the World Economy. November 15.

G20. (2009). Leaders' Statement. The Pittsburgh Summit. September 24-25.

G20. (2011). Building Our Common Future: Renewed Collective Action for the Benefit of All. Cannes Summit Final Declaration, November 4.

Kenen, Peter B. (2001). The International Financial Architecture: What's New? What's Missing? Washington, D.C.: Institute for International Economics.

Kerwer, Dieter. (2005). Rules that Many Use: Standards and Global Regulation. Governance: An International Journal of Policy, Administration, and Institutions, 18(4), 611-632. http://dx.doi.org/10.1111/j.1468-0491.2005.00294.x

Kose, M. Ayhan, \& Eswar, Prasad. (2004). Liberalizing Capital. Finance \& Development, September, 50-51.

Larionova, Marina (2011). Assessing G8 and G20 Effectiveness in Global Governance so far. International Organizations Research Institute, National Research University Higher School of Economics.

North, Douglass C. (2005). Institutions and the Process of Economic Change. Management International, 9(3), 1-7.

Porter, Tony. (2005). Globalization and Finance. Cambridge, UK: Polity Press.

Rodrik, Dani. (1999). Governing the Global Economy: Does One Architectural Style Fit All? Paper prepared for the Brookings Institution Trade Policy Forum conference on Governing in a Global Economy, April 15-16.

Rodrik, Dani. (2001). The Global Governance of Trade as if Development Really Mattered. New York: United Nations Development Programme.

Rodrik, Dani. (2009). A Plan B for Global Finance. The Economist, 12 March.

Sheng, Andrew. (2009). The Global Public Good is Being Consumed by Unfettered Greed and Momentum Trading. The Warwick Commission on International Financial Reform: In Praise of Unlevel Playing Fields, Foreword.

Singh, Ajit. (2002). Corporate Governance, the Big Business Groups and the G7 Reform Agenda: A Critical Analysis. Seoul Journal of Economics, 15(2), 103-148.

Stiglitz, Joseph E. (1998). International Financial Institutions and the Provision of International Public Goods. EIB Papers, 3(2), 116-132.

Stiglitz, Joseph E. (1999). The World Bank at the Millennium. The Economic Journal, 109, F577-F597. http://dx.doi.org/10.1111/1468-0297.00473

Stiglitz, Joseph E. (2002a). Globalization and the Logic of International Collective Action: Re-examining the Bretton Woods Institutions. In Deepak Nayyar (Ed.), Governing Globalization. Oxford Scholar Online.

Stiglitz, Joseph E. (2002b). Globalization and its Discontents. London: Penguin Books.

Stiglitz, Joseph E. (2006). Global Public Goods and Global Finance: Does Global Governance ensure that the Global Public Interest is Served? In J-P Touffut (Ed.), Advancing Public Goods. Cheltenham, UK: Edward Elgar Publishing. http://dx.doi.org/10.4337/9781847201843.00016

Stiglitz, Joseph E. (2008a). Is there a Post-Washington Consensus Consensus? In N. Serra and J. E. Stiglitz (Eds.), The Washington Consensus Reconsidered: Towards a New Global Governance. New York: Oxford University Press. http://dx.doi.org/10.1093/acprof:oso/9780199534081.003.0004

Stiglitz, Joseph E. (2008b). The Future of Global Governance. In N. Serra and J. E. Stiglitz (Eds.), The Washington Consensus Reconsidered: Towards a New Global Governance. New York: Oxford University Press. http://dx.doi.org/10.1093/acprof:oso/9780199534081.003.0014 
Stiglitz, Joseph E. (2010). Contagion, Liberalization, and the Optimal Structure of Globalization. Journal of Globalization and Development, 1(2), Article 2.

Volcker, Paul A. (2000). The Implication of Globalism is Globalism. Journal of International Financial Management and Accounting, 11(3), 207-214. http://dx.doi.org/10.1111/1467-646X.00063

Wade, Robert. (2007). The Aftermath of the Asian Financial Crisis: From "Liberalize the Market" to "Standardize the Market" and Create a 'Level Playing Field'. In B. Muchhala (Ed.), Ten Years After: Revisiting the Asian Financial Crisis. Washington, D.C.: Woodrow Wilson International Center for Scholars.

Wade, Robert. (2008). Financial Regime Change? New Left Review, 53, 5-21.

Williamson, John. (2000). What Should the World Bank think about the Washington Consensus? The World Bank Research Observer, 15(2), 251-264. http://dx.doi.org/10.1093/wbro/15.2.251.

Wyplosz, Charles. (1999). International Financial Instability. In I. Kaul, I Grunberg, and M. Stern (Eds.), Global Public Goods: International Cooperation in the 21st Century. New York: Oxford University Press. http://dx.doi.org/10.1093/0195130529.003.0009

\section{Notes}

Note 1. Acharya et al. (2009a:370) use the phrase 'beggar-thy-neighbour' in the case of "regulatory externality" which refers to the national competitive approach to regulation without international coordination that will lead to a race to the bottom in regulatory standards.

Note 2. It includes: (1) fiscal discipline; (2) a redirection of public expenditure priorities toward fields offering both high economic returns and the potential to improve income distribution; (3) tax reform; (4) interest rate liberalization; (5) a competitive exchange rate; (6) trade liberalization; (7) liberalization of inflows of foreign direct investment; (8) privatization; (9) deregulation (to abolish barriers to entry and exit); and (10) secure property rights.

Note 3. The twelve areas of international standards: (1) Data Dissemination; (2) Fiscal Transparency; (3) Transparency in Monetary and Financial Policies; (4) Banking Supervision; (5) Securities Regulation; (6) Insurance Supervision; (7) Payments and Settlements; (8) Corporate Governance; (9) Accounting; (10) Auditing; (11) Insolvency and Creditor Rights; and (12) Anti-Money Laundering and Combating the Financing of Terrorism.

Note 4. https://www.conference-board.org/data/bci/index.cfm?id=2154.

Note 5. Interest rate spread is calculated as the lending rate minus deposit rate. Interest rate spread is the interest rate charged by banks on loans to prime customers minus the interest rate paid by commercial or similar banks for demand, time, or savings deposits. It serves as an indicator of bank profitability/performance and competitiveness.

Note 6. Officially Hong Kong is not a country itself, but it is grouped under country classification for this particular research purpose.

Note 7. By 2014, some Euro-zone countries such as Greece and Spain were still suffering from the effects of the GCC, but for the purpose of this paper, we put a crisis end date of 2010 by assuming that substantial amount of the adverse effects had already dissipated in most countries.

Note 8. Alan Greenspan on the US ABC's "This Week" in September 2008. See also "Greenspan: Economy in 'once in-a-century' crisis", CNNMoney.com, September 14, 2008; and "Market crisis 'will happen again", interview with Alan Greenspan, BBC News (part of BBC Two's Love of Money series), September 8, 2009.

Note 9. This is followed by the rather high trade index volatility of $18.90 \%$.

Note 10. The G20 was foreshadowed at the Cologne Summit of the G7 in June 1999 and was formally established at the G7 Finance Ministers' meeting in September 1999. The G20 superseded the G33, which itself replaced the G22 in early 1999. In the wake of the Asian financial crisis, the establishment of the Group of 22 (G22), on a temporary basis, was announced by President Clinton of the US and leaders of Asia-Pacific Economic Cooperation (APEC) countries at their meeting in Vancouver in November 1997, when they agreed to organize a gathering of Finance Ministers and Central Bank Governors to advance the reform of the global financial architecture.

Note 11 . Member countries represent around $90 \%$ of global gross national product, $80 \%$ of world trade (including EU intra-trade) as well as two-thirds of the world's population. 